\title{
Rapid detection of infectious laryngotracheitis virus by standardization of polymerase chain reaction targeting a relatively conserved region of the thymidine kinase gene
}

\section{S. Chakma ${ }^{1}$, S. Sarker ${ }^{*}$, S. Talukder ${ }^{2}$, M.H. Haque ${ }^{3}$, E.H. Chowdhury ${ }^{1}$ and A.S.M. Bari ${ }^{1}$}

${ }^{1}$ Department of Pathology, Bangladesh Agricultural University, Mymensingh-2202, Bangladesh, ${ }^{2}$ Department of Animal Science and Nutrition, Chittagong Veterinary and Animal Sciences University, Khulshi, Chittagong-4202, Bangladesh,

${ }^{3}$ Department of Animal Husbandry and Veterinary Science, University of Rajshahi, Rajshahi-6205, Bangladesh.

*Corresponding author: DR. Subir Sarker, Department of Animal Husbandry and Veterinary Science, University of Rajshahi, Rajshahi-6205, Bangladesh; E-mail: subir_ahvs@ru.ac.bd

\begin{abstract}
Infectious laryngotracheitis is an acute upper respiratory tract infection of chickens caused by infectious laryngotracheitis virus. The study was conducted to standardize the polymerase chain reaction targeting a relatively conserved region of the thymidine kinase gene for the rapid detection of infectious laryngotracheitis virus. The vaccine samples were collected from two renowned company of Bangladesh. DNA was extracted from diluted vaccine samples by using Wizard $^{\circledR}$ Genomic DNA purification kit and thymidine kinase gene was amplified by using PCR system 9600 Thermocycler. Two vaccine samples were positively amplified by polymerase chain reaction. A procedure was developed for rapid detection of infectious laryngotracheitis virus by polymerase chain reaction of the conserved region of viral thymidine kinase gene containing DNA fragments. The results obtained in this study suggested that the polymerase chain reaction procedure could serve as a fast and sensitive method for the detection of vaccine strains of infectious laryngotracheitis viruses.
\end{abstract}

Key words: Infectious laryngotracheitis virus, viral thymidine kinase (TK) gene, polymerase chain reaction

\section{Introduction}

Infectious laryngotracheitis (ILT) is a worldwide distributed upper respiratory disease of chickens (Guy \& Bagust, 2003) and included within the list E of the Office International Des Epizooties (OIE) (Hidalgo, 2003). Chicken is the only significant primary host species for infectious laryngotracheitis virus (ILTV) and no other reservoir species have been recognized, even though pheasant and peafowl can sometimes be naturally infected by contact with chickens actively shedding ILTV (Guy \& Bagust, 2003). Infection is acquired via the upper respiratory tract and transmission occurs most readily from acutely infected birds but clinically inapparent infection can persist for long periods with intermittent re-excretion of the virus, and these recovered carrier birds are also a potential means of transmission of the disease (OIE, 2008). The disease is common in areas of intense poultry production and causes great economic losses due to moderate to severe mortality, and drop in egg production (Callison et al., 2007).

Strains of infectious laryngotracheitis virus may vary considerably in their virulence and there was evidence that vaccine derived strains have become established in the field (Graham et al., 2000). This ability of ILTV vaccine strains to recirculate may also be responsible for some outbreaks in susceptible birds, as passage in birds has been reported to result in increasing virulence (Guy et al., 1991), while stress in latently infected birds has also been demonstrated to be responsible for the re-excretion of ILTV (Bagust et al., 2000).

Conventional laboratory diagnosis of ILT is based on virus isolation in specific pathogen free chicken embryos inoculated via the chorioallantoic route or in primary chicken embryo kidney cells, chicken embryo liver cell (Tripathy, 1998). However, it is time consuming and labor intensive in spite of its high sensitivity and specificity. The use of direct fluorescent-labeled polyclonal antibodies (FA) to detect viral antigens in tracheal and conjunctival smears (Goodwin et al., 1991), or monoclonal antibodies to detect viral antigens in frozen tracheal sections have been successfully utilized in the rapid diagnosis of the disease, although those had comparatively poor sensitivity. 
Therefore, a requirement for the development of rapid and sensitive diagnostic techniques for the verification of clinical diagnosis of ILTV for the improvement of the quality of surveillance systems. As such, the present study was carried out to standardize the polymerase chain reaction (PCR) targeting a relatively conserved region of the thymidine kinase (TK) gene for the rapid detection of ILT virus.

\section{Materials and Methods}

\section{Collection of samples for DNA extraction}

The Nobilis ${ }^{\circledR}$ ILT and Gallivac LT freeze dried vaccine samples were collected respectively from the Intervet, Bengal Overseas Limited and Advance Animal Science Company Limited, Dhaka, Bangladesh, and carried in an ice box to the Department of Pathology, Faculty of Veterinary Science, Bangladesh Agricultural
University, Mymensingh. The vaccine was diluted with the given sterile buffered and colored solvent and stored at $2-8^{\circ} \mathrm{C}$.

\section{DNA extraction}

DNA was extracted from diluted vaccine samples by using Wizard ${ }^{\circledR}$ Genomic DNA purification kit (Promegra Corporation. 2800 Woods Hollow Road. Madison, USA). The extracted DNA was quantified using a spectrophotometer's (Spectronic $^{\circledR}$ Genetics $^{\text {TM }}$ New York, USA) and expressed in $\mathrm{ng} / \mu \mathrm{l}$.

\section{Selection and synthesis of primers}

An appropriate primer sequence for PCR was selected to amplify thymidine kinase (TK) gene (Griffin \& Boursnell, 1990) of ILT virus. The primer sequences (Table 1) were synthesized commercially by Sangamo Biosciences, Inc., Singapore.

Table 1. Primers used in PCR for infectious laryngotracheitis detection

\begin{tabular}{|c|c|c|c|c|}
\hline Primer & $\begin{array}{l}\text { Target } \\
\text { Gene }\end{array}$ & Sequence & $\begin{array}{c}\text { Product } \\
\text { Size }\end{array}$ & Location \\
\hline $\begin{array}{l}\text { ILTV } \\
\text { PCR5' }\end{array}$ & \multirow[t]{2}{*}{ TK gene } & 5'-ACGATGACTCCGACTTTC-3' & \multirow[t]{2}{*}{ 647bp } & \multirow{2}{*}{$\begin{array}{l}\text { The ILTVPCR5' primer starts at } \\
\text { base } 222 \text { in the keeler sequence } \\
\text { and base } 4501 \text { in the Griffin } \\
\text { sequence. The ILTPCR3' primer } \\
\text { starts at base } 847 \text { in the keeler } \\
\text { sequence and base } 5130 \text { in the } \\
\text { Griffin sequence. }\end{array}$} \\
\hline $\begin{array}{c}\text { ILTV } \\
\text { PCR3' }\end{array}$ & & 5'-CGTTGGAGGTAGGTGGTA-3' & & \\
\hline
\end{tabular}

\section{Amplification of DNA by polymerase chain reaction (PCR)}

PCR amplification was performed in a final volume of $10 \mu$ l containing $2 \mu$ l of extracted DNA template, Taq DNA polymerase buffer (10x) $1 \mu \mathrm{l}$, dNTPs $1 \mu \mathrm{l}$, primer-F (50n mol) $0.5 \mu \mathrm{l}$, primer-R (50n mol) $0.5 \mu \mathrm{l}$, Taq DNA polymerase $0.2 \mu \mathrm{l}$ and $4.8 \mu \mathrm{l}$ nuclease free water (Science Park Rd.\#0123, The Geni S'pore). $2 \mu \mathrm{l}$ water was added instead of DNA to the water control tube. Amplification was carried out in Gene amplification PCR system 9600 Thermocycler (eppendorf, Germany), using condition modified from Abbas et al., (1996). The pre-mix was then mixed well through spinning. Initial denaturation was at $94^{\circ} \mathrm{C}$ for $1 \mathrm{~min}$, again denaturation was at $95^{\circ} \mathrm{C}$ for 1 minute, annealing at $50^{\circ} \mathrm{C}$ for 1 minute and extension at $72^{\circ} \mathrm{C}$ for 1.5 minutes, with a final extension at $72^{\circ} \mathrm{C}$ for 5 minutes for total 35 cycles and held for $4^{\circ} \mathrm{C}$ in refrigerator until electrophoresis.

\section{Agarose gel electrophoresis}

The amplified PCR products were separated by electrophoresis on $1.5 \%$ agarose gel containing $5 \mu \mathrm{ml}^{-1}$ ethidium bromide with a 100 bp ladder (Promega, Madison, WI, USA) as molecular weight marker (Oliveira et al., 2003).

\section{Documentation of the PCR products}

After electrophoresis, the gel was taken out carefully from the gel chamber and placed on the UV Transilluminator in the dark chamber of the Image Documentation System (Labortechnik, Germany).

\section{Results and Discussion}

Polymerase chain reaction was optimized and evaluated by the amplification with primers made from targeted portion of thymidine kinase (TK) gene of the ILTV. The PCR was performed at different annealing temperatures and products of 647-bp were successfully amplified at $50^{\circ} \mathrm{C}$ 
annealing temperature. The expected fragment of 647-bp of the thymidine kinase gene of ILTV was obtained from two samples, as well as no band was detected in the negative control (Fig 1). The positive result in the PCR directed to the thymidine kinase gene of infectious laryngotracheitis virus (ILTV) agrees with the findings of Abbas et al. (1996).

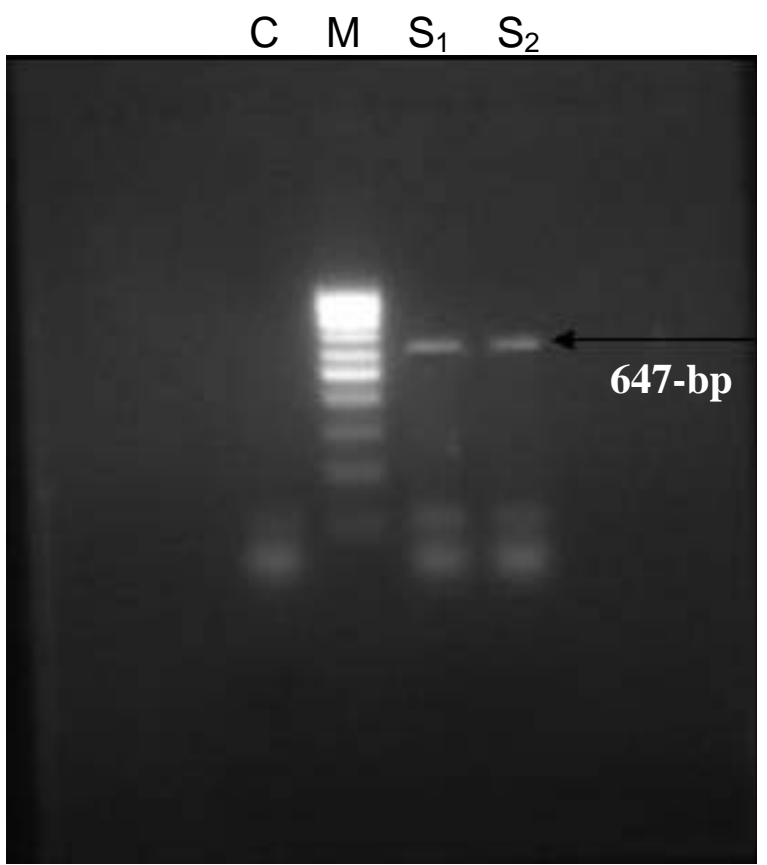

Fig 1. Visualization of the 647-bp PCR product from the thymidine kinase gene of ILTV by agarose gel electrophoresis $(1.5 \%)$ after staining with ethidium bromide. Lane-S ${ }_{1}$ : viral vaccine (Nobilis ${ }^{\circledR}$ ILT); Lane-S ${ }_{2}$ : viral vaccine (Gallivac LT); Lane-M: molecular marker; Lane -C: negative control

Molecular based diagnostic methodologies, such as DNA probes (Key et al., 1994) and the polymerase chain reaction (Williams et al., 1994; Abbas et al., 1996) have been developed to diagnose the infectious laryngotracheitis virus. The positive results in the PCR directed to the thymidine kinase gene of ILTV is a useful tool to confirm the diagnosis of birds suspected to infectious laryngotracheitis. Results can be obtained in less than 24 hours which is an essential point in outbreaks when fast decisions are required. The application of the procedures described herein must be evaluated for field sample collected from suspected birds considering that PCR applied to viral diagnosis is a highly sensitive technique (Forghani \& Erdman, 1994) that allows the detection of infection in a very early phase when compared to serological reactions (Pang et al., 2002).
In spite of the use of vaccines for the control of ILTV, the disease continues to be a problem in commercial poultry (Clavijo \& Nagy, 1997). The use of live and modified live vaccines has been demonstrated to lead to spread of the virus, particularly within 7-10 days of vaccination. Carriers may result, and it is possible that the infection become indigenous and thus the vaccine strains of the virus may be involved in ILTV outbreaks (Hughes et al., 1987). These findings provide support for the requirement of continuous monitoring of the vaccine strains and the development of molecular techniques that may allow simple and reliable identification of different vaccine strains.

\section{Acknowledgements}

The authors would like to express the deepest sense of gratitude to the Department of Pathology, Bangladesh Agricultural University, Mymensingh for providing laboratory facilities with necessary research materials.

\section{References}

Abbas, F., Andreasen, J.R. \& Jackwood, M.W. 1996. Development of a Polymerase chain reaction and a nonradioactive DNA probe for infectious laryngotracheitis virus. Avian Dis. 40:56-62.

Bagust, T.J., Jones, R.C. \& Guy, J.S. 2000. Avian infectious laryngotracheitis. Rev. Sci. Tech. 19:483492.

Callison, S.A., Riblet, S.M., Oldoni, I., Sun, S., Zavala, G., Williams, S., Resurreccion, R.S., Spackman, E. \& Garcia, M. 2007. Development and validation of a real-time Taqman PCR assay for the detection and quantitation of infectious laryngotracheitis virus in poultry. J. Virol. Metho. 139:31-38.

Clavijo, A. \& Nagy, E. 1997. Differentiation of infectious laryngotracheitis virus strains by polymerase chain reaction. Avian Dis. 41:241-246.

Forghani, B. \& Erdman, D.D. 1994. Amplification and detection of viral nucleic acids. In: Schmidt JN, Emmons RW. Diagnostic procedures for viral, rickettsial and chlamydial infections. Washington, DC: American Public Health Association. pp. 97120.

Goodwin, M.A., Smeltzer, M.A., Brown, J., Resurreccion, R.S. \& Dickson, T.G. 1991. Comparison of histopathology to the direct immunofluorescent antibody test for the diagnosis of infectious laryngotracheitis in chickens. Avian Dis. 35:389-391. 
Graham, D.A., McLaren, T.E., Calvert, V.M., Torrens, D. \& Meehan, B.M. 2000. RFLP analysis of recent Northern Ireland isolates of infectious laryngotracheitis virus: Comparison with vaccine virus and field isolates from England, Scotland and the Republic of Ireland. Avian Pathol. 29:57-62.

Griffin, A.M. \& Boursnell, M.E.G. 1990. Analysis of the nucleotide sequence of DNA from the region of the thymidine kinase gene of infectious laryngotracheitis virus; potential evolutionary relationships between the herpesvirus subfamilies. J. Gen. Virol. 71:841-850.

Guy, J.S. \& Bagust, T.J. 2003. Laringotracheitis. In: Saif Y.M., Barnes, H. J., Fadly, A. M., Glisson, J. R., McDougald L. R. and Swayne, D. E. (eds.) Diseases of poultry (11th edn.). pp. 121-134. Iowa State University Press, Amer. IA.

Guy, J.S., Barnes, H.J. \& Smith, L.G. 1991. Increased virulence of modified-live infectious laryngotracheitis vaccine virus following bird-to-bird passage. Avian Dis. 35:348-355.

Hidalgo, H. 2003. Infectious laryngotracheitis: A Review. Brazilian J. of Poul. Sci. 5: 157-168.

Hughes, C.S., Jones, R.C., Gaskel, R.M., Jordan, F.T.W. \& Bradbury, J.M. 1987. Demonstration in live chickens of the carrier state in infectious laryngotracheitis. Res. Vet. Sci. 42:407-410.

Key, D.W., Gough, B.C., Derbyshire, J.B. \& Nagy, E. 1994. Development and evaluation of a nonisotopically labelled DNA probe for the diagnosis of infectious laryngotracheitis. Avian Dis. 38:467-474.

OIE, 2008. OIE Terrestrial Manual. Chapter 2.3.3 Avian infectious laryngotracheitis.
Oliveira, S.D., Roclenbuisch, C.R., Ce, M.C., Rocha, S.L.S. \& Canal, C.W. 2003. Evaluation of selective and non- selective enriched PCR procedures for Salmonella detection. Letters in Application Microbiology. 36:217-221.

Pang, Y., Wang, H., Girshick, T., Xie, Z. \& Khan, M. 2002. Development and application of a multiplex polymerase chain reaction for avian respiratory agents. Avian Dis. 46:691-699.

Tripathy, D.N. 1998. Infectious laryngotracheitis. In: Swayne, D. E., Glisson, J. R., Jackwood, M. W., Pearson, J. E., Reed, W. M. (Eds.), A laboratory Manual for the isolation and identification of Avian pathogens. American Association of Avian Pathologist, Kennett Square, PA, pp. 111-115.

Williams, R.A., Savage, C.E. \& Jones, R.C. 1994. A comparison of direct electron microscopy, virus isolation and a DNA amplification method for the detection of avian infectious laryngotracheitis virus in field material. Avian Pathol. 23:709-720. 